Незважаючи на точність поетичних та літературно-теоретичних визначень аспектів сміху у літературних текстах, в тлумаченнях фантастики часто наявна неточність, що $є$ результатом неоднозначного використання термінів жартівливого, комічного, іронічного, пародійного, сатиричного та под. Іронія та фантастика належать до різних видів вираження, тому важко систематизувати їхні відношення. У тексті пропонується типологія взаємозв'язку іронії та фантастики, заснована на ролі іронії та іронічного відхилення / коментаря у зображенні світу - в представленому реальному світі, в дивовижному світі та в проблематизації взаємозв'язку між реальним та дивовижним світом. Цей нарис, у подальшому буде підкриплений інтерпретаціями конкретних творів слов'янської фантастичної літератури, що імовірно дозволить вдосконалити та уточнити запроплновані теоретічні положення.

\title{
REFERENCES:
}

1. Ajdačić D. (2015) Parodija i satira u prikazima demona u slovenskim književnostima 19. veka. In: Slov'jans'ka fantastika. Zbirnyk naukovyh prac, tom. 2. Red. Dejan Ajdačič, Kyiv, 2015, s. 7-24.

2. Jankelevič [Jankélévitch] V. (1989) Ironija, Sremski Karlovci.

3. Mann J. (2007) Russkaja literatura XIX veka. Epoha romantizma, Moskva, 2007.

4. Stojanović D. (2018) Svečani čas pripovesti. Josif i njegova braća, Beograd.

5. Stojanović D. (1984) Ironija i značenje, Beograd.

6. Struc' R. (1998) Riznovydy ironiji Naukovi zapysky NaUKMA. Filologija, Kyiv, tom 4, 37-42.

7. Żmigrodzka M. (2002) Ironia romantyczna, Stownik literatury polskiej XIX vieku, Red.

A. Kowalczykowa J. Bachórz, Warszawa.

Білик $\boldsymbol{H}$.

д.ф.н., доц., Київський національний університет імені Тараса Шевченка (Украӥна)

Bilyk N.

Doctor Hab., Associate Professor, Taras Shevchenko National University of

Kyiv (Ukraine)

\author{
ІНТЕРМЕДІАЛЬНІСТЬ ТА ЕКФРАЗИС \\ У РОМАНАХ М. ПАВИЧА
}




\section{INTERMEDIATION AND EXFRASIS IN M. PAVICH'S NOVELS}

Особливим продуктивним напрямом компаративістичної стратегї наразі вважаються багатоманітні взаємини різних медіа. 3 а узагальненою типологією з-поміж типів інтермедійності на сучасному етапі найпліднішими й найефективнішими слід вважати, зокрема екфразис та інтермедіальність особливий прояв інтермедійності, явище конкретного виражального посередництва - медіаторства - одного медіа в образному полі іншого. Інтермедіальному формату, розбудованому взаємодією різних знакових систем $i$ закодованого ними змісту, переважно - літератури та інших мистецтв 3 акцентом на знаково-смисловій відповідності зіставлень, притаманна суттєва художня ефективність. Водночас, переважним визначальником екфразису як опису твору мистеитва в літературному тексті пропонується вважати його зв'язок із конкретною авторською роботою, хоча припускається також поширення екфразису на аналогічні або неіснуючі, але жанрово конвенціональні художні варіанти із достеменним наслідуванням відповідної мистецької поетики. У визначенні універсальних спільних принцииів організації такої суверенності знакових систем, позиџіонованих у статусі локальних варіантів різних дискурсивних практик у прочесі їхньої синкретичної взаємодії в літературному вимірі, ефективними для висвітлення порушеного питання видаються передусім тендениії екфрастичного напряму літературознавства, започатковані семіотичною кониепцією Ю. Лотмана, $i$ насамперед теорією накладання й перетину смислових просторів, здатних породжувати новий смисл. Емпірика інтермедіальності та екфразису яскраво й переконливо актуалізується в романах видатного сербського письменника М. Павича. Посутні інтермедіальні та екфрастичні імпровізачії вияскравлюються у слкладній, багатоплановій організаиії поетики форми романів, наголоменій у літературознавчих працях, які вивели цей постулат на рівень традиційних наукових поглядів. Новаторський творчий досвід мития, висвітлений у творах «Хозарський словник», «Внутрішній бік вітру», «Остання любов у Царгороді», "Друге тіло» засвідчує окрему витонченість, змістовність, влучність оформлення й різноспрямованість та осяжність значеннєвого потенціалу, щуо 
наближає прояви поетики синкретизму мистеитвв до організаційних формосмислових компонентів образної будови роману загалом.

Ключові слова: компаративістика, інтермедіальність, екфразис, М. Павич.

The multifaceted interrelationships of the various media are now considered to be a particular productive area of comparative strategy. The generalized typology among the types of intermedia at the present stage is considered to be the most fruitful and effective, in particular, ephrasis and intermedia - a particular manifestation of intermedia, the phenomenon of specific expressive mediation - mediation - of one media in the figurative field of another. Intermediate format, developed by the interaction of different sign systems and the content encoded by them, mainly literature and other arts with emphasis on the sign and semantic correspondence of comparisons, has significant artistic effectiveness. At the same time, the preferred determinant of ephrasis as a description of a work of art in a literary text is suggested to be its relation to a specific work of authorship, although it also assumes the spread of the ephrasis to similar or non-existent but genre conventional art variants with a pre-eminent inheritance of the corresponding art. In determining the universal common principles of organizing such sovereignty of sign systems, positioned in the status of local variants of different discursive practices in the process of their syncretic interaction in the literary dimension, effective for illuminating the raised issue are primarily the tendencies of the extracurricular direction of literary criticism, initiated by the first concept. the imposition and intersection of semantic spaces capable of generating new meaning. The empiricism of intermedia and ephrasis is vividly and convincingly actualized in the novels of the prominent Serbian writer M. Pavic. Intermediate and extravagant improvisations are evident in the complex, multifaceted organization of the poetics of the novel form, emphasized in literary works, which brought this postulate to the level of traditional scientific views. Innovative creative experience of the artist, covered in the works of "Khazar Dictionary», "Inner Side of the Wind», "Last Love in Constantinople», «The Second Body», attests to the individual sophistication, content, precision of design and variety of potential, meaningfulness, significance poetics of syncretism of the arts to the organizational form-meaning components of the figurative structure of the novel as a whole.

Key words: comparative studies, intermediality, exphrasis, M. Pavich. 
На сучасному етапі еволюціонування наукових напрямів нові концепції компаративістики розвивають релевантну тезу, пов'язану з принциповим збагаченням літературознавчого досвіду. Особливим продуктивним напрямом компаративістичної стратегії наразі вважаються багатоманітні взаємини різних медіа, виокремлених свого часу канадським філософом, філологом і теоретиком ЗМІ М. Маклюеном, чиїми ідеями закладені підвалини не лише математичного, а й філософського напряму досліджень функціонування всіх можливих матеріальних і нематеріальних феноменів як медійних систем [Маклюен 2011].

Академічними науковими дискусіями третього тисячоліття, присвяченими проблематиці літератури в колі найрізноманітніших медій, насамперед позиціями послідовників уславленої традиції німецьких учених - представників новітньої германістики [Потемкина 2010], сучасних українських літературознавців Я. Поліщука, О. Бандровської, Ю. Починок, Н. Мочернюк [Шостий 2013] було оприявлене окреслення дефінітивних берегів, у яких загальне, універсальне явище будь-якої взаємодії між численними медіа різних сфер людської діяльності дістало назву інтермедійності.

За узагальненою типологією з-поміж типів інтермедійності на сучасному етапі найпліднішими й найефективнішими слід вважати, зокрема екфразис та інтермедіальність - особливий прояв інтермедійності, явище конкретного виражального посередництва медіаторства - одного медіа в образному полі іншого [Білик 2018, 29].

Суттєва художня ефективність в інтермедійному прояві інтердискурсивності притаманна інтермедіальному формату, розбудованому взаємодією різних знакових систем і закодованого ними змісту, переважно - літератури та інших мистецтв 3 наголошеним T. Бовсунівською акцентом на знаково-смисловій відповідності зіставлень [Бовсунівська 2013: 13]. 
Принцип досягнення плідності інтермедіальності наразі виводиться від здатності поетики оприявнювати зокрема зазначену М. Наєнком екранність або театральність літератури [Наєнко 2016: 14], а також наголошену О. Тимашковим музичність прози [Тимашков], де, наприклад, виражальні засоби нелітературного виду мистецтва організують простір літературного твору таким чином, аби (на відміну від опису) створити образ із використанням рис, питомих для іншого виду мистецтва й за компонентним принципом генерувати, або увиразнити його зміст.

Функціонально-смисловий план екфразису в осяжній перспективі інтердискурсивності, за типологією В. Т. Мітчелла [Mitchell 1995: 2122], розгортається в берегах способу репрезентаиії різних видів мистецтва в літературі. Відтак, беззаперечно приймається позначений ученим так званий «титульний бік екфразису», здійснений «наданням голосу німому твору мистецтва» або його характерним рисам [Мітчелл 2013: 24]. Себто, в ідентифікації та осмисленні даного явища цілком раціонально виходити 3 дисциплінарного принципу екфразису, за яким активований у ньому початковий візуальний об'єкт не тяжіє (окрім як шляхом аналогій) над художнім описом, він ніколи не може бути присутній, але має посилатися на знаковий образ, у якому він даною співприсутністю реалізує своє значення й набуває додаткового кодування у вигляді передбачених цим значенням конотацій. Концептуальним пунктом висвітлення, за Мітчелловою позицією, стає критерій відношення «зображення/текст», яке не обмежується феноменологічною моделлю, натомість бере на себе повний набір імовірних відношень так званого «соціального» типу, включених до сфери вербальної та візуальної репрезентації. Дане уявлення про понятійну основу явища дає змогу зрозуміти в його функціональності не лише об'єкт, але й наповнену змістом репрезентативну форму, яка мотивує i визначає герменевтичний фактор іiі існування [Мітчелл 
2013: 27-34]. Р. Бобрик схильний наблизити зміст даного явища до категорії інтерпретації настільки, наскільки будь-яке висловлювання про мистецтво $€$ його інтерпретацією, що, на його думку, зі змістової точки зору, тотожна словесному еквіваленту, а можливо, й «копії» [Бобрик 2013: 70-74]. Уточнене дефінітивне наповнення розукрупнює явище екфразису, дозволяє ввести до параметрів його висвітлення ситуативно ефективні інтерпретаційні виміри, що сприяє детальнішому висвітленню його семантичного результату.

Переважним, але не обов'язковим визначальником екфразису як опису твору мистецтва в літературному тексті, за спостереженнями Р. Бобрика, пропонується вважати його зв'язок із конкретною авторською роботою, хоча припускається також поширення екфразису на аналогічні або неіснуючі, але жанрово конвенціональні художні варіанти із достеменним наслідуванням відповідної мистецької поетики [Бобрик 2013: 76].

Протягом $\mathrm{XX}$ сторіччя в компаративістичному дискурсі був продукований і синтезований значний досвід, який сформував можливість відкривати нові грані феномена екфразису та відповідної йому стратегії порівняльного літературознавства, де неминучим поліметодологічним підходом оприявився відчутний потенціал синтезу літературознавчого та мистецтвознавчого інструментарію.

Особливого значення в ситуації, коли об’єкт зображення в літературному творі співпадає з об'єктом зображення в інших видах мистецтва, набуває Лессингове проголошення повної суверенності та своєрідності різних мистецтв [Бобрик 2013: 68]. У визначенні універсальних спільних принципів організації такої суверенності знакових систем, позиціонованих у статусі локальних варіантів різних дискурсивних практик у процесі їхньої синкретичної взаємодії в літературному вимірі, ефективними для висвітлення порушеного питання видаються передусім тенденції екфрастичного напряму літературознавства, започатковані семіотичною концепцією Ю. Лотмана, 
i насамперед теорією накладання $\check{u}$ перетину смислових просторів, здатних породжувати новий смисл [Лотман 2000: 27].

I Кінцева функціональна фаза синкретизації художньої сфери, за власною іманентною природою, і передбаченими нею спільними якостями та принципами реалізації, відтак, забезпечується властивістю сягнути гносеологічного виміру й передбачає розкриття передбаченого та гіпотетичного типів змістів. У дебатах щодо процедури значеннєвої

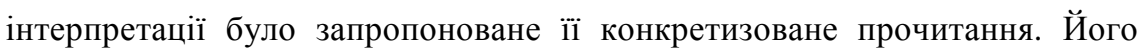
узагальнена версія, за Т. Бовсунівською, містить кілька етапів, зосереджених, відповідно, на первісному змісті (фактичному, експресивному), умовному та внутрішньому, або символічному значенні [Бовсунівська 2013: 14].

За спостереженнями О. Тимашкова, найактивніша взаємодія медійної і літературної сфер розвивається переважно в полі своєрідного діалогу між субстанціями літератури та різних видів мистецтв [Тимашков], що, вочевидь, слід передбачити й у зразках сербської романістики порубіжжя XX-XXI сторіч.

Посутні інтермедіальні та екфрастичні імпровізації вияскравлюються, зокрема, у слкладній, багатоплановій організації поетики форми романів М. Павича, наголошеній у літературознавчих працях, які вивели цей постулат на рівень традиційних наукових поглядів (Татаренко 2010). Показовим компонентом Павичевих романів визнаємо образну матерію, відповідну інтермедіальності, помітну в організації низки творів. Її форма взаємного інтегрування різних знакових систем, за хронологією, репрезентується «Хозарським словником», чия архітектоніка організована за моделлю словника й образна матерія посилена оприявленням репродукиій, пов'язаних із корелятами інтертекстуальних прототекстів. Вияскравлюються передусім фотокопії титульної сторінки перекладу латиною книги про хозар [Pavić 1988: 235] і водяного знаку зі збірки Абу-Кабіра Муавії [Pavić 1988: 174], репродукція портрета 
Мефодія Солунського, за фрескою IX ст. [Pavić 1988: 83] тощо. Суттєву аналогію у взаємодії різних знакових систем помічаємо в романі «Остання любов у Царгороді...» [Pavić 2004], де кожен розділ починається репродукцією малюнка на карті таро, з чиєю символікою цей розділ пов'язаний. Аналогічний прийом з'являється й у творі «Друге тіло», чий образний матеріал оздоблюється графічними включеннями із зображенням концептуальних атрибутів художньої дійсності - ескізом зведеної церкви Святого Миколая і символічного хреста, мальованого на щастя й надію [Pavić 2006: 244-245], обрисом системи координат, чиї вісі визначені категоріями «вічності» й «часу» [Pavić 2006: 224], фотокопією фрагмента партитури із нотним записом композиції відомого представника сербського мистецтва XVIII сторіччя й видатного представника історії національної культури сербів Захаріє Орфеліна [Pavić 2006: 53] тощо. Подібним включенням збагачується й роман «Краєвид, мальований чаєм» - у ньому оприсутнюється репродукція креслення так званої «блакитної мечеті», омріяної в юнацтві одним із протагоністів - архітектором Разіним [Павић 2012: 230].

Плідно урізноманітнюють створену митцем образну парадигму риси, актуальні для екфразису. Їх варто вирізнити в локальному фрагменті роману «Внутрішній бік вітру...», в описі прадавньої ікони з Пелагонії, де представлені Богородиця 3 немовлям і чоловік із бородою - а саме, святий Іоанн Хреститель - який стояв біля них, і в цій композиції ікони проглядалася неперервана лінія, що поєднувала фігури, подібна до замкненого кола - лінія, схожа на літеру фіта [Павић 1995]. Слід погодитися 3 позицією П. Піяновича [Пијановић 1998: 254] стосовно формосмислової ваги даного екфразису, вочевидь покликаного згуртувати в нерозривну суміщену завершену єдність сюжетні контури протиставно зічленованих доль, чий перетин позначився фактором, який, зазвичай, прийнято вважати символом нездоланності - часом, аби переконатися в невідворотності співпадіння ліній, скерованих взаємним 
призначенням. Окрім того, в романі унаочнюється й опис музичного артефакту - скрипки і виконаної на ній мелодії, на чиє звучання під час пам'ятного концерту озвалося все, з чого створена природа [Павић 1995].

Згорнутий музичний екфразис вибудовується й у романі «Друге тіло». Ідеться про опис музики, метафорично поцінованої на вагу «проходження крізь лабіринт» ${ }^{*}$ [Pavić 2006: 113], та співу ретельно занотованої у рукописах і не виконуваної раніше нещодавно написаної пісні Захаріє Орфеліна, незбагненним чином відомої незнайомій йому дівчині: тоді його «розбудила музика. Із сусіднього приміщення чулися цимбали, а потому залунав і жіночий альт, гарячий, немов напій, зварений на чорному цукрі» ${ }^{* *}$ [Pavić 2006: 52]. Потому видніє й екфразис іншого - посутнього контекстуального - звукового плану: «із сусідньої кімнати знову було чути цимбали, але то грала не Анна, це можна було одразу зрозуміти по застрашливій, майже механічній швидкості пальців <..> Музика почала дихати й із неї вийшло дещо жахливе, що не було музикою <..>. Звуки змішалися зі звуками дзвонів» ${ }^{* * *}$ [Pavić 2006: 60], і такий опис мелодії: «виконавцю краще вдавалися мажорні, аніж мінорні зони, легато було згущене і біле <...> Ритм дещо переміщений на несподівані місця й на межі припустимого. У Ляйпцігу це називалося rubatto: першу ноту в такті незнайомець трохи затримував і композиція справляла враження написаної тактом на три чверті, а не на чотири чверті. Потім з'являвся presto $<\ldots>$ на певних тонах чулося дещо подібне втомі, ніби місця на клавіатурі лякаються пальців виконавця <...> Найчастіше на ноті ре й рідше на ноті $\phi a$, але

\footnotetext{
**provlačenje kroz lavirint».

«probudila ga je muzika. Iz susedne prostorije čulo se čembalo, a zatim se oglasio i ženski alt vreo poput pića kuvanog na crnome šećeru».

*** «Iz susedne odaje čuo se opet čembalo, ali to nije svirala Ana, to se moglo odmah poznati po strahovitoj, gotovo mehaničkoj hitrini prstiju $<\ldots$. Muzika je počela da diše i iz nje izlazi nešto strašno što nije muzika <...>. Zvuci su se mešali sa zvukom zvona».
} 
лише в теноровій октаві клавіатури» " [Pavić 2006: 75-76]. Змальовується в романі й уявна «звукова нитка»* : «звук був протяглий, доволі високий $<\ldots>$. Він не був надто сильним $<\ldots>$ Рівний, без зміни висоти і сили, він спускався 3 неба на Землю, немов найтонше стрімке повітря або водоспад» ${ }^{* * *}$ [Pavić 2006: 111].

Таким чином, у контексті компаративістичних експериментів висвітлений новаторський досвід інтермедіальності та екфразису в творах М. Павича «Хозарський словник», «Внутрішній бік вітру...», «Остання любов у Царгороді...», «Друге тіло» засвідчує окрему витонченість, змістовність, влучність оформлення й різноспрямованість та осяжність значеннєвого потенціалу, що наближає прояви поетики синкретизму мистецтв до організаційних формосмислових компонентів образної будови роману.

\section{REFERENCES:}

1. Bilyk N. L. (2018) Stratehiyi komparatyvistyky v serbs'komu romani porubizhzhya 20-21 storich: Monohrafiya. Kyiv. (in Ukr)

2. Bobryk R. (2013) Deyaki sposterezhennya nad vzayemozv"yazkamy literatury y zhyvopysu In: Ekfrazys: verbal'ni obrazy mystetstva: monohrafiya / za red. T. Bovsunivs'koyi; per. z anhl. I. Malishevs'koyi, z pol. ta ros. D. Lytovchenka. Kyiv. (in Russ)

3. Bovsunivs'ka T. (2013) Synkretyzm mystetstv i stanovlennya teoriyi ekfrazysu. In: Ekfrazys: verbal'ni obrazy mystetstva: monohrafiya / za red. T. Bovsunivs'koyi; per. z anhl. I. Malishevs'koyi, z pol. ta ros. D. Lytovchenka. Kyiv. (In Ukr)

\footnotetext{
* «Osobi koja je svirala više su ležale durske nego molske zone, legato je bilo zgusnuto i belo <...>. Ritam malo pomeren na neočekivana mesta i na granici dopuštenog. U Lajpcigu se to zvalo rubatto: prvu notu u taktu nepoznati je malo zadržavao tako da je kompozicija delovala kao da je pisana u tročetvrtinskom, a ne četiričetvrtinskom taktu. Zatim naiđe jedan presto $<. . .>$ na nekim tonovima čulo se nešto kao umor, kao da su ta mesta na klaviaturi čimbala plašila prste svirača. <...> Češće na dirci re i nešto ređe na dirci fa ali samo na tenorskoj oktavi klavijature».

** «zvučna nit».

*** 《Zvuk je bio otegnut, dosta visok <...>. Nije bio naročito jak <...>. Ravan, ne menjaući visinu ni jačinu, sruštao se on s neba na Zemlju kao tanušan okomit zrak ili slap vode».
} 
4. Lotman YU. (2000) Semyosfera. Kul'tura y vzryv. Vnutry myslyashchykh myrov. Stat'y. Yssledovanyya. Sankt-Peterburg. (In Russ)

5. Maklyuen M. (2011) Ponymanye medya. Moskva. (In Russ)

6. Mitchell W. T. (1995) Picture Theory: Essays on Verbal and Visual Representation. University of Chicago Press.

7. Nayenko M.K. (2016) Intermedial'nist' yak metodolohiya. In: Filolohichni seminary. Intermedial'nist': teoriya i praktyka: Zb. nauk. prats'. Vyp. 19.

8. Pavić M. (2006) Drugo telo. Beograd.

9. Pavić M. (1988) Hazarski rečnik: ženski primerak. Roman leksikon u 100.000 reči. Beograd:, Priština, Novi Sad.

10. Pavić M. (2004) Poslednja ljubav u Carigradu: Priručnik za gatanje. Beograd.

11. Pavyć M. (1995) Unutrashn̂a strana vetra yly Roman o Khery y Leandru. Beohrad. (in Serb)

12. Pavyć M. (2012) Predeo slykan chajem. Beohrad. (in Serb)

13. Pyjanovyć P. (1998) Pavyć. Beohrad. (in Serb)

14. Potemkyna M.S., Cherenok Y.H. (2010) Konhress mezhdunarodnoho soyuza hermanystov. Varshava. Rezhym dostupa: https://cyberleninka.ru/article/v/kongressmezhdunarodnogo-soyuza-germanistov-varshava-2010. (In Russ)

15. Shostyy Mizhnarodnyy mizhdystsyplinarnyy teoretychnyy sympozium «Literatura v koli mediy: intermediyne pole khudozhnikh praktyk, retseptyvni stratehiyi, syntez mystetstv», traven' 2013 (2013) / Instytut literatury im. T.H. Shevchenka NAN Ukrayiny. Kyiv. (In Ukr)

16. Tymashkov A.S. K ystoryy ponyatyya yntermedyal'nosty v zarubezhnoy nauke. Rezhym dostupa: www.spbric.org/PDF/tim08_1.pdf. (In Russ)

17. Tatarenko A. (2010) Poetyka formy v prozi postmodernizmu (dosvid serbs'koyi literatury). L'viv. (In Ukr).

Деркач $О$.

к.ф.н., Київський національний університет імені Тараса Шевченка

(Україна)

Derkach $O$.

PhD., Taras Shevchenko National University of Kyiv (Ukraine)

\section{ДО ПИТАННЯ ІСТОРІЇ ПЕРЕКЛАДІВ СЕРБСЬКОЇ ПРОЗИ В УКРАЇНІ: ДІАХРОНІЧНИЙ АСПЕКТ}

